\title{
LIVING VALUES NEMZETKÖZI OKTATÁSI PROGRAM A NEUMAN JÁNOS EGYETEM PEDAGÓGUSKÉPZÓ́ KARÁN
}

\section{LIVING VALUES INTERNATIONAL EDUCATION PROGRAM ON TEACHER TRAINING FACULTY OF JOHN VON NEUMANN UNIVERSITY}

\author{
Fried Zsófia ${ }^{1}$ \\ ${ }^{1}$ Belső Értékeinket Kibontakoztató Egyesület, Magyarország
}

\author{
Kulcsszavak: \\ értékrend \\ jóság \\ személyiség \\ pedagógusképzés \\ gyermekek \\ Keywords: \\ scale of values \\ goodness \\ personality \\ teacher training \\ children
}

\begin{abstract}
Összefoglalás
A Belső Értékeink Nemzetközi Oktatási Program (Living Values Education) létrejöttének leglényegesebb indítéka, hogy a bennünk lévő jót/belső értékeinket „élôvé”, a mindennapjaink részévé tegyük, és így egy olyan értékrendet mutassunk gyermekeinknek, ami az életüket minőségivé teszi. A program elsősorban pedagógusoknak, szülőknek, nagyszülőknek, (gyermekeink közvetlen környezetének), és a gyermekeknek szól. A cikk 20172018. tanév 2. félévében a Neumann János Egyetem Pedagógusképző Karán, a "Pedagógusok belső eszköztára: Pedagógus személyiségünkkel közvetített belső értékeink.” címmel indított választható kurzus hallgatóinak és a foglalkozásokat vezetö tanárnak a tapasztalataiból ad izelítöt.
\end{abstract}

\section{Abstract}

The main motive why the "Living Values Education" international program was establish to make alive our goodness/our inner values, to make them the part of our life, in order to show our children a values-system which makes their life qualitative. The program is first of all for teachers, for parents, for grandparents (who are directly around the children) and for children. The article is about experiences of the students and the Teacher who facilitated the curse with the title: "Inner tools of Teachers: Our inner values through our personalities as Teachers" in the frame of "Living Values Education" on Teacher Training Faculty of John von Neumann University in the second semester in 2017-2018 school year.

\footnotetext{
1 Kapcsolattartó szerző. Tel.: +36-1-3778855

E-mail cím: hungary@livingvalues.net
} 


\section{Bevezetés}

A Living Values Education (LVE) - az UNICEF által életre keltett és UNESCO által is támogatott - program magyarországi koordinátoraként 2000 óta foglalkozom a program megismertetésével, tréningek tervezésével és irányításával pedagógusoknak, szülőknek, valamint gyermekeknek. A program lényege: Ha szeretnénk, hogy a gyermekeink önmaguk és mások megbecsülésén alapuló értékrend mintát kapjanak, akkor azt elsősorban nekünk, pedagógusoknak és szülőknek kell számukra megmutatnunk, közvetítenünk. Ehhez azonban alapvető, hogy mi magunk is a saját jóságunk, a mindegyikünkben ott lévő értékek alapján éljünk. Mindegyikünkben ott van a jó, csak a legtöbb esetben ezt nem hisszük el, vagy ha el is hisszük, beszélünk róluk, de nem igazán merjük ezeket használni a minden napi életünkben. Olyan is előfordul, hogy egyszerüen félreértjük az olyan szavaknak a jelentését, mint szeretet, tisztelet, alázat, egyszerűség, kedvesség, stb. Sokszor az is előfordul, hogy ezeknek a használatát elvárjuk tanítványainktól, gyermekeinktől, de a mi életünknek nem válnak a részeivé.

\section{2. „Pedagógusok belső eszköztára: pedagógus személyiségünkkel közvetített belső értékeink" címú választható kurzus}

A pedagógusoknak először 30 órás pedagógus továbbképzőket szerveztünk Sue Emery nemzetközi tréner közremúködésével. Azonban egy 30 órás továbbképző ízelítőt adhat a program megismeréséhez, alapvető tapasztalatok szerzéséhez, de hogy ezek az értékek, valóban beépüljenek a mindennapjainkba, ennél sokkal hosszabb időre, és állandó gyakorlásra van szükségünk. Nem kell tökéletesnek lenni, de csak akkor lehetünk hitelesek, ha a tanítványaink, gyermekeink érzik, hogy az az út, amit nekik mutatunk, a mi utunk is. Egyre jobban éreztem, hogy ennek a programnak a pedagógusképzésben a helye. Magam is pedagógusnak tanultam, és az egyetem végzése közben és utána is hiányérzetem volt. Lehet, hogy olyanok kerültek ki a képzésből, akik tantárgyi ismerete kiváló volt, de arra nem emlékszem, hogy valaha is mélyebben megvizsgálták volna, hogy mennyire vagyunk alkalmasak arra, hogy a gyerekekhez jól közelítsünk, hogyan teremtsünk velük kapcsolatot és azt hogyan fejleszthetjük, illetve hogyan tehetjük ezeket a kapcsolatokat hosszabb távon tartóssá. Úgy gondolom, hogy a szaktárgyak ismeretével párhuzamosan nagyon fontos, hogy a pedagógusok stabilak, kedvesek és egyben támaszok is legyenek a gyermekek számára.

Amikor 1999-ben egy athéni tanár barátom felhívta a figyelmemet az LVE programra, akkor volt egy olyan érzésem, hogy talán ez lehet az, ami az elóbbiekben említett „hiányérzetem” megszüntetheti. A program részletesebb megismerése, a nemzetközi tréningeken való részvétel, és a különböző országokban müködő kollégákkal történő beszélgetések a megérzésemet meggyőződéssé tették. Természetesen ennek a meggyőződésnek az alapját a program tanításakor szerzett tapasztalataim adják.

Igazán nagy megtiszteltetésnek éreztem, amikor Dr. Molnár Edina főiskolai tanár felkért, hogy fakultációként próbáljuk ki a program létjogosultságát a pedagógusképzésben is.

A tapasztalataim felülmúlták a várakozásaimat. Heti egy alkalommal 2x45 perces foglalkozásokat tartottunk. A kurzusra 25-en jelentkeztek és végül 21-en kaptak gyakorlati jegyet.

Egyszer-egyszer, ha sikerült, akkor megpróbáltam egyénileg is beszélgetni velük. Sokféleképpen érzékelték a kurzust. Volt, aki úgy érezte, hogy nagy szükség van arra, amit itt tanulhatnak, volt, aki azt mondta, hogy igen, ez szép lenne, de hát a mai világban így nem lehet az értékeink alapján élni, mert csak a mókus kerék van. Amikor megkérdeztem, hogy miért nem, akkor nem tudott mit válaszolni. (Megjegyzem, hogy a kurzus végére a véleménye megváltozott.) De mindez számomra érthető, mert mint ahogy az emberek általában nincsenek hozzászokva ahhoz, hogy ilyen módon ismerkedjenek, gondolkodjanak, vagy beszéljenek magukról, így ők sem. Volt, aki egyik óra után azt mondta, hogy ôt mindig megnyugtatják az órák és felfrissül. Egy biztos, hogy egyre nyitottabbakká és aktívabbakká váltak. Ahhoz is elég nehezen szoktak hozzá, hogy ezeken az órákon bármit mondhattak, minden jó volt.

Minden alkalommal nem hagyományos „házi feladatot” is adtam. A házi feladat lényege mindig az volt, hogy az órán megismert értékkel kapcsolatban mindenki válasszon magának valamilyen „feladatot”, amit gyakorolhat a következő hétig. Bár maga a feladat mindig egyszerü 
volt; pl. együttmúködés önmagammal, kritikus helyzetekben hogyan teszem magam nyugodttá, békéssé, egy-egy helyzetben magamban és másokban meglátom-e a jót, mennyire vagyok nyitott, vagy az elő́téletek, mások véleménye (vagy igaz, vagy nem) befolyásolja a cselekedeteimet, képes vagyok értően meghallgatni másokat, stb. Nagyon értékeltem, hogy szinte mindegyikük próbálkozott. Ezek nem egyik napról a másikra „bemagolható” dolgok. Sok időt kell szánnunk a gyakorlása, mert a szokásaink nagyon erőteljesek, és sokszor akaratunk ellenére is használjuk azokat. Előbb-utóbb, szinte mindenki kezdte érzékelni, hogy a hozzáállás, a látásmód mennyire befolyásolja nemcsak a mindennapi életünket, hanem ez határozza meg pedagógus mivoltunkat is. Márpedig a hozzáállás és a látásmód annak a függvénye, hogy a bennem lévő értékek mennyire jelennek meg, mennyire használom a hétköznapjaimban.

Nem hibátlannak kell lennünk -ilyen ember nincs - de az fontos, hogy amiről beszélek, azt is tegyem, különben nem vagyok hiteles. A tiszteletet csak akkor kaphatjuk meg, ha tiszteletet adunk.

\section{A kurzus hallgatói értékelése}

Az utolsó alkalommal megkértem a jelenlévőket, hogy töltsenek ki egy értékelő lapot, név nélkül. Nézzük meg a kérdésekre adott válaszaik egy részét.

\subsection{Mit viszel magaddal a mindennapjaidba a fakultáción tanultakból?}

- Úgy gondolom, hogy nagyon sok mindent. Sokat tanultam, próbálok jobban figyelni másokra és önmagamra. Jobban belemélyedtem egy-egy tulajdonságba, és jobban megismertem önmagamat.

- Nagyon sok mindent viszek magammal. Megtanultam meglátni magamban a jót, melytől a világot is sokkal pozitívabban látom. Elég sokat stresszelek, de tanultam néhány praktikát, hogy elhessegessem a negatív gondolataim. Úgy érzem, hogy ez a kurzus a lehető legjobbkor jött nekem.

- Biztosan jobban oda fogok figyelni azokra a dolgokra, amiket az órán beszéltünk. A mindennapokban is hasznosak lesznek, például, hogy ha egyszer tanítani fogok, akkor szeretném, hogy a tanulók is megismerkedjenek ezekkel a dolgokkal. Tudjam, hogy miért fontos az öntisztelet és a felelősség.

- Az egyszerüségre törekvést. A minél jobb időbeosztást, melyen belül, minden számomra fontos tevékenységre szánok időt. Másokra való odafigyelést.

- Azt hiszem, hogy ezek után mindennap gondolok magamra. Gondolok a saját belső békémre, a sikereimre, amiket eddig elértem, és így talán minden napom könnyebb lesz.

- Higgadtság, együttmúködés magammal.

- Szeretném előtérbe helyezni azt, hogy a jó tulajdonságaim (amik itt derültek ki számomra), a mindennapjaim részei legyenek, tudjak úgy élni, hogy alkalmazom őket.

- Észre tudom venni a mindennapi apró örömöket, nemcsak a nagy dolgokra koncentrálok. Saját magamra, egy kicsit a lelki békémre is rátaláltam.

- Nagyon sok mindent. A kurzuson említett értékekről rengeteg új dolgot megtudtam, segített más szemszögből átgondolni, látni őket. Természetesen továbbra is gyakorolni fogom őket.

- A fakultáción tanultakból a magamra való odafigyelést, a pozitív dolgokra való odafigyelést, mások meghallgatását viszem magammal. Könnyebben megnyílok mások elött.

- Jobban értékelem a kis dolgokat az életben. Megbecsülöm azt, amim van. Tisztelem magam akkor is, ha hibázok.

- A társ tiszteletnél sokkal fontosabb az öntisztelet. Ennek a segítségével ismerhetjük meg magunkat igazán, ami alapja a kielégítő szociális életünknek is.

- Próbálok jobban figyelni magamra. Jobban egyensúlyban lenni önmagammal, tisztelni önmagamat. Mindenben igyekszem a jót meglátni. 
- Úgy érzem, hogy könnyebben meglátom a jó dolgokat a mindennapokban. Emellett, amikor ideges vagyok, igyekszem az itt hallott praktikákat használni.

- Sokkal türelmesebb, toleránsabb viselkedést produkálok a fakultáció kezdete óta, elfogadóbb lettem.

- Úgy érzem, sok mindent tanultam önmagamról ezalatt a néhány hét alatt: megtanultam értékelni a jó tulajdonságaimat, és azt, hogy hogyan lehet a rossz tulajdonságokat jóra fordítani. Gyakoroltam az együttmúködést másokkal, magammal és az idővel.

- Odafigyelek, hogy azokat a tulajdonságaimat, amelyeket kevésbé használok, többet gyakoroljam. Nem mondom azt, hogy valamilyen jó tulajdonsággal nem rendelkezem, megtanultam, hogy minden megvan bennem, csak használnom kell.

- Megpróbálom magamban és másokban is észrevenni a jót. Ha valakinek arra van szüksége, akkor örömmel meghallgatom, felelősséget vállalok a tetteimért.

- Tiszteljem magam.

- A pozitív életszemléletet. A negatív energia kisöprését, pozitív emlékek felszínre hozatalát. Nyitottságot magam és mások felé. Együttmúködést másokkal magammal. Pozitívabb önértékelést, önbecsülést.

\subsection{Mely rész/részek volt/voltak számodra a leghasznosabbak?}

- Az a rész volt a leghasznosabb, amikor a békéről tanultunk, rengeteg praktikát kaptunk! Valamint az együttmúködés másokkal, önmagunkkal és az idővel rész volt rendkívüli hasznos. Azóta sokkal hatékonyabban végzem a feladataimat.

- A leghasznosabb rész számomra az önismereti volt, a kurzus legeleje, illetve az öntisztelet, mert akkor eszembe jutottak olyan dolgok, volt időm gondolni olyanokra, amelyekre máskor nincs.

- Öntisztelet, aktív hallgatás - egymásra való odafigyelés.

- Nem tudok egyet választani. Mind ugyan annyira volt hasznos számomra.

- Együttmúködés magammal, aktív hallgatás.

- Öntisztelet, úgy gondolom, hogy az mindenképpen hasznos volt, hogy megtanulhattuk tisztelni saját magunkat.

- Legfóképpen a béke és az alázat, mint téma volt a leghasznosabb, mivel jelenleg a magánéletemben is fontos és középpontba került. Így jó volt ezekről beszélgetni, meghallgatni mások véleményét, belemélyedni a dologba.

- A beszélgetések során a tisztelet és a béke voltak számomra a leghasznosabbak.

- Öntisztelet, elfogadás, béke, együttmúködés.

- Egyszerüség, alázat.

- Minden foglalkozáson tanultam valami hasznosat, ami építő jellegü számomra. De kiemelném a tiszteletről és az alázatról szóló órát.

- A beszélgetések által, hétről-hétre könnyebben nyíltam meg számomra idegen emberek felé.

- Önismereti részek, amikor magammal ismerkedtem meg jobban, és nem kértek számon utána, hiszen úgy gondolom, hogy ez magánügy.

- Számomra a leghasznosabb „téma” az idővel való együttmúködés volt, hiszen sajnos nagyon rosszul szoktam beosztani az időmet.

- Számomra a felelősségről szóló rész volt a leghasznosabb. Én hajlamos voltam mindent magamra vállalni, de már tudom, hogy mindenki magáért felelős. Nekem az a felelősségem mással szemben, hogy rosszat ne tegyek, de nem rajtam múlik az ő élete.

- Együttmúködés. Sokat tanultam arról, hogy az együttmúködés nem csak csoportban valósul meg, hanem együttmúködhetek magammal is, amit azóta is próbálok minél jobban megvalósítani. Ö̉ntisztelet. Sajnos általában a rossz tulajdonságaimat veszem észre. Ezen a kurzuson megtudhattam, hogy valójában mennyi jó tulajdonságom van.

- Számomra nagyon hasznos volt, amikor olyan tulajdonságokat kellett gyakorolni, amiket nem használok a mindennapokban. Azáltal, hogy gyakoroltam, észrevettem, hogy 1-2-öt már napi rendszerességgel alkalmazok, mint pl. a türelem.

- Nagyon tetszett, hogy csiga-szerüen fel kellett írni a gondolataimat, nehéz volt olykorolykor, de rendszerezte az értékeimet. Jó volt a „fás” feladat is, amikor a gyümölcsökre 
a sikereket kellett írni, a gyökerekre pedig a tulajdonságokat, majd összekötni egymással. Nehéz volt nemcsak kimondott nagyobb sikerekre gondolni, hanem arra is, amikor magamat szárnyaltam felül. Pozitívabban gondolkodom, úgy, hogy nem arra gondolok, hogy mi bosszant a múltból, hanem hogy milyen jó dolgok történtek velem.

\subsection{Volt-e olyan terület, amellyel még foglalkoztál volna, és szívesen hallanál még róla?}

- Szerintem a legfontosabb dolgokat átvettük, de szívesen részt vennék még a tanévben foglalkozáson.

- Szerintem mindegyik téma megérdemelne még plusz órákat, de nem éreztem hiányosságokat. Teljesen egyén függő, hogy ki mit mennyit tud meríteni belőle. Számomra pontosan elég volt ahhoz, hogy megvilágítson dolgokat, melyek a mélyről a felszínre törnek.

- Szívesen beszélgettem volna a szeretetről, hiszen az egy nagyon furcsa dolog, amely pillanatok alatt tud változni. Az órán elhangzottak közül pedig azzal a résszel foglalkoztam volna még, amelyek a saját tulajdonságainkkal foglalkoztak.

- Időbeosztás, önbizalom növelése.

- Siker és a béke.

- Együttmüködés az idővel.

- A másokkal, illetve a magunkkal való együttmúködésről még szívesen hallanék, nagyon hasznos témának tartom.

- A kapcsolatok területét szívesen érintettem volna, akár a család, párkapcsolat, munkahely.

- A tisztelet, az öntisztelet értékekkel foglalkoztam volna még többet, hiszen ez nagyon fontos a mindennapi életünkben is, de mint pedagógus szintén nagy hangsúlyt kap majd.

- Az alázattal még szívesen foglalkoztam volna.

- Együttmúködés, tisztelet.

- Béke (sajnos az órán nem tudtam gyakorlat miatt jelen lenni.)

- A boldogság témával foglalkoztam volna még szívesen.

- Az együttmúködéssel, főleg az idővel. Ebben még fejlődnöm kell.

- Amikor az egyszerüség volt a téma, sajnos nem tudtam megjelenni az órán, mivel hospitáltam. Erdekelt volna ez a téma.

- $\quad$ Minden területtel szívesen foglalkoznék még.

- Együttmúködés magammal, az idővel és másokkal. Alázat.

- $\quad$ Az idővel való együttmúködés, öntisztelet.

- Szeretettel, tisztelettel még többet foglalkoztam volna. Illetve a boldogság is nagyon fontos, fontos bástya. Azonban minden érték rendkívül fontos, mindenre időt kell szorítani. Örökké elemezhetnénk magunkat és másokat. Mindig tanulunk valamit az életben.

\subsection{Milyen javaslataid vannak?}

- Esetleg még játékos feladatokat tennék bele az órába.

- Kellene olyan rész, ami csak azzal foglalkozik, hogy kissé több legyen az önbizalom.

- Az órát lehetne olyan feladattal színesíteni, hogy egy például egy konkrét szituációt eljátszanának a hallgatók, és utána a látottak alapján beszélnénk meg az érzéseket, észrevételeket.

- A vizualizációk nagyon hasznosak voltak, úgy gondolom, hogy abból még több lehetne a jövőben.

- Több játékos feladat lehetne az órákon. Az órai tapasztalataim alapján, ha játékba van burkolva a beszélgetés, akkor sokkal könnyedebben válaszolnak, osztják meg az érzéseiket, véleményeiket a tanulók.

- U Úgy vettem észre, hogy a csoport aktívabb volt, ha valamilyen játékos feladat volt. 
- Érdemes lenne valahogy megszürni azokat az embereket, aki nem vették komolyan, csak a kredit miatt voltak itt, Sokkal hatásosabb lenne az óra, olyanokkal, akiket tényleg érdekel.

- Összességében tetszett a kurzus. Talán kevesebb témát dolgozhatnánk fel, és még alaposabban.

- Nekem összességében tetszett, de szerintem egy picit többet is mozoghattunk volna, mert sokszor kellett nagyon koncentrálni, és elfáradtam. Jól esett volna egy kis mozgás.

- Elégedett voltam az órák levezetésével, mintaértékű volt. Lehet, hogy többször sorba kellene menni, mert így mindenki azt várja, hogy a másik is megszólaljon. Pedig mindenkinek van gondolata a legtöbb esetben.

\subsection{Milyen érzésekkel mész el?}

- Nagyon jól éreztem magam a kurzus során, és próbáltam is minden órán részt venni.

- Nagyon jó érzésekkel. Remélem, következő félévben is meg lesz hirdetve a kurzus, szívesen felvenném.

- $\quad$ Nekem nagyon tetszett a kurzus, fóleg, hogy több mindent tudtam meg magamról, és most már azt is tudom, hogy hogyan változhatok.

- Ha idegesen is jöttem, mindig nyugodtabban hagytam el a termet. Megnyugtató órák voltak.

- Az órák után általában sokkal békésebb voltam, és mindig jó érzés volt bennem, hiszen tanultam magamról valami pozitívat. Ez ma sincs másként.

- Jó tapasztalat volt, örülök, hogy részt vettem.

- Hasznosnak, jónak tartottam a kurzust. Jó érzésekkel megyek el.

- Pozitív érzésekkel megyek el az órákról.

- Nagyon kellemes érzésekkel. Jó volt beszélgetni az értékekről. Nem gyakran fordul elő, hogy elgondolkozunk ezeken a dolgokon, pedig olyan alapvetőnek gondoljuk.

- Pozitív érzésekkel gazdagodtam. Többet tanultam meg önmagamról, érzéseimről.

- Örülök, hogy részt vettem a kurzuson, ezzel is közelebb kerülve magamhoz és társaimhoz.

- Pozitív érzésekkel távozom a kurzusról.

- Minden óráról, így erről is, pozitív érzésekkel megyek el. Jó volt egy kicsit megállni a mindennapokban, és gondolkodni.

- Jó érzésekkel megyek el, köszönöm, hogy jobban megismerhettem magam. Hasznos volt.

- Úgy gondolom, hogy hasznosítani fogom az itt tanultakat, így örülök, hogy felvettem a kurzust.

- Pozitív érzésekkel. Örülök, hogy felvettem ezt az órát.

- Jó érzésekkel megyek el, megkönnyebbülten, és már képesnek látom magam olyan dolgokra, amikre eddig nem.

- Jó érzésekkel távozom a kurzusról, hiszen minden alkalommal elgondolkodtam, és jutott valami jó az eszembe, ami jó érzésekkel töltött el. Sok hasznos dolgot tanultam.

- Számomra jó érzésekkel távozok, hiszen itt legalább volt időm megismerni magam, mert sajnos ebben a mai rohanó világban kevés időt tudok szánni, és jó érzés volt ez a heti 1,5 óra, hogy kicsit magammal is foglalkozzak.

\section{Köszönetnyilvánítás}

Köszönettel tartozunk a kutatás támogatásáért, amely az EFOP-3.6.1-16-2016-00006„A kutatási potenciál fejlesztése és bővítése a Neumann János Egyetemen” pályázat keretében valósult meg. A projekt a Magyar Állam és az Európai Unió támogatásával, az Európai Szociális Alap társfinanszírozásával, a Széchenyi 2020 program keretében valósul meg.

\section{Irodalomjegyzék}

[1] Hawkes, Neil. (2003) How to inspire and develope positive values in your classroom. Printed in UK for LDA

[2] Tilmann, D. and Hsu, D. (2000). Living Values Activities for Children Ages 3-7. Deerfield, FL.: HCL

[3] Tilmann, D. (2000). Living Values Activities For Children Ages 8-14. Deerfield, FL.: HCL 
[4] Tilmann, D. (2000). Living Values Activities for Young Adults. Deerfield, FL.: HCL

[5] Tilmann, D. (2000). Living Values Parent Groups: A Facilitator Guide. Deerfield, FL.: HCL

[6] Tilmann, D. and Quera Colomina, P. (2000). LVEP Educator Training Guide. Deerfield, FL.: HCL

[7] UNESCO. 1995 United Nations Year for Tolerance. Paris: Office of Public Information, UNESCO, 1995 Available at the U.N. Bookstore.

[8] Universal Declaration of Human Rights - An Adaptation for Children. New York: U.N. Publications, 1992. Sales \#E.89.1.19(H) 92-1100424-1. 46pp Available at the U.N. Bookstore. 